\title{
DEPOSIT AND FINANCING INSTRUMENTS THROUGH WAQF BANK FOR FOSTERING REAL ECONOMY AND SOCIAL SUSTAINABILITY
}

\author{
Muhammad Ridhwan Ab. Aziz ${ }^{1 *}$, Mohd Asyraf Yusof ${ }^{2}$ \\ *Corresponding author: \\ ${ }^{1}$ Faculty of Economics and Muamalat, Universiti Sains Islam Malaysia, Bandar Baru Nilai, 71800, Negeri Sembilan, Malaysia. \\ ridhwan.aziz@usim.edu.my. \\ ${ }^{2}$ Faculty of Economics and Muamalat, Universiti Sains Islam Malaysia, Bandar Baru Nilai, 71800, Negeri Sembilan, Malaysia. \\ muhammadasyrafyusof@gmail.com.
}

\begin{abstract}
During the global financial crisis and its aftermath, Islamic financial institutions were less affected, protected by their fundamental operating principles of risk sharing and the avoidance of leverage and speculative financial products. This has led to a greater appreciation of the role of Islamic finance in supporting economic growth across the globe. The contribution of Islamic finance and Islamic social finance especially through waqf sector promotes real economic development and could help to foster real economy and social sustainability. The impact and contribution of waqf for economic development in fostering real economy and social sustainability can be obverved in many areas such as enhancing economic progress, eradicating proverty, restoring distribution of income, reducing government expenditure, preventing deficit financing and stimulate growth and job creation. Therefore, a new mechanism is needed to support non-bankable and poor customers for financing facilities via Shariah compliant Islamic financial products and services. The purpose of this paper is to examine the most feasible mechanism for deposit and financing instruments based on waqf through Waqf Bank that able to foster and stimulate economic and social sustainability in the real economy sector especially for Muslim countries. The methodology of research in this study is through qualitative research based on interviews with Muslim scholars as well as Islamic banking and waqf practitioners. The finding of this study shows that there is feasible mechanism and modus operandi for the development of deposit and financing instruments in the Waqf Bank that able to be applied in many Muslim countries worldwide.
\end{abstract}

Keywords : Waqf bank, islamic banking and finance, islamic social finance, real economy and sustainability

\section{INTRODUCTION}

Waqf may be defined as holding a mal or property from the consumption for the purposed of extracting the usufruct for the benefit of the Muslim society. The word waqf is derived from the Arabic word 'waqafa' means 'causing a thing to stop and standhill'. It also takes the meanings of 'detention', 'holding' or 'keeping'. This definition also covers several new forms of waqf that were not discussed in the classical literatures, such as waqf of financial rights and waqfof usufruct (Kahf, Monzer, 1998).

The waqf properties consist of immovable assets such as land and buildings and also the movable assets such as money and shares. The concept of waqf also extends to the concept of cash waqf where the usage of cash money to be endowed as the waqf property instead of the real estate. The application of cash waqf has been founded since the $8^{\text {th }}$ century when Imam Zufar had approved this concept. According to him, cash waqf would be invested through mudarabahand profits would be spent for charity (Murat Cizakca, 2004; Muhammad Ridhwan Ab.Aziz et. al., 2013).

During the Ottoman era, cash waqf has supported by the Ottoman Sultans because funds were financed in the expansion of Islam in Europe. Besides, the cash waqf is more important 
because the cash is more flexible and more productive rather than land, buildings, books etc. Nowadays, the concept of cashwaqf gives more opportunity for the Muslims to endow their cash money into the waqf institutions in order to get various benefits not only for themselves, but also to other Muslims worldwide (Murat Cizakca, 1998).

Thus, the idea and suggestion to establisha new alternative instrument of deposit and financing through waqf bank for Muslims especially in giving their cash money for the endowment certainly a timely and good attempt for the benefit of the ummah. It can be done by depositing their money through the waqf bank as a waqf money. Anyone can become al-waqif (donor) through cash waqf subject to certain Shariah conditions.

The waqf bank can play its role as a trust fund to provide services for the Muslim development. The waqf bank can provide the financial services to the Muslims in many fields without taking a lot of profits or at very minimum rate, without riba' and all the prohibited elements. The objective of this study is to examine and propose deposit and financing instruments for waqf bank that able to be applied effectively in the market and Islamic finance industry.

\section{Concept of Waqf and Fostering Economic and Social Sustainability Through Waqf}

Waqf which (pl. Awqaf) is called Boniyad in Iran and Habs(pl. Ahbas) in North and West Africa. However, by taking its different meanings into consideration waqf can be applied to nonperishable property whose benefit is extracted without consuming the property itself. Although, waqf is not specifically mentioned in the Holy Quran, the concept of wealth distribution is strongly emphasized therein (Chowdhury et.al, 2011). Distribution of wealth is a key issue in the modern economy to make it more dynamic, prejudice free and entrepreneurial. However, a hadith narrated by Abu Hurairah [May Allah be pleased with him (RA)] is considered as the origin of this institution in the world of Islam. Abu Hurairah (RA) reported Prophet Muhammad SAW as saying: "when a man dies, all his acts come to an end, but three; recurring charity (sadaqahjariyah) or knowledge (by which people are benefited), or a pious offspring, who prays for him" (Reported by Muslim, No. 4223).

From Shariah point of view, waqf may be defined as holding a mal (an asset) and preventing its consumption for the purpose of repeatedly extracting its usufruct for the benefit of an objective representing righteousness or philanthropy. This definition also covers several new forms of waqf that were not discussed in the classical literature, such as the waqf of financial rights and waqf of usufruct, are covered by the definition of the word mal(asset) according to the majority of fuqaha and as expressly mentioned in the collective fatawa, especially the OIC Fiqh Academy (MonzerKahf, 1998). The contemporary jurists also justify the validity of the cash waqf, because it is in the interest of the waqf, its beneficiaries and the society (Tahir, 2011). In addition, waqf assets can also be immoveable or moveable (e.g. cash waqf). In cash waqf, al-waqif (donor) endowed cash instead of real estate. In the eighth century, Imam Zufar had approved cash waqf in the Islamic World for the first time (Cizakca, 2004, 2010). Meanwhile, the distribution of productive funds will be right on target so that it can narrow the gap between the rich and the poor(RB Dandy Raga Utamaet.al, 2018). 
Social institutions such as zakat and waqf are essential tools towards achieving sustainable economic development if they are incorporated into Islamic financial system. If they are properly executed, they can play a major role towards unemployment and poverty elimination, eventually contributing towards real economic development (MIFC, 2015). In Malaysia for instance, Islamic Financial Institutions (IFIs) have thus, far played its role towards the fulfillment of zakat and waqf. For example, Bank Islam Malaysia Berhad (BIMB) and Maybank Islamic Berhad offer online zakat and waqf services so as to help both the IFIs and the Muslim society to fulfill their obligations and create greater awareness on the importance of zakat and waqf towards improving the social welfare of Muslim community (MIF Report, 2015).

Waqf, as a voluntary social institution, is governed by the principles of perpetuity, inalienability and irrevocability. It is widely known that through proper administration of waqf, the existing gap between contemporary Islamic finance and its socioeconomic aspects can therefore be addressed, thus achieving its real economic goals. The institution of waqf has the potential to create robust not-for-profit entities that may address education, healthcare and other social needs in the Muslim societies, thus unlocking both its economic potentials and philanthropic objectives (MIFC, 2015).

GCC has accordingly played its role towards waqf development. For example, the Central Bank of Bahrain and the IFIs together established the waqf fund in 2006 and proceeds generated from this fund are allocated to finance training, education and research at various levels in the Islamic finance industry (Bernama, 2014). Islamic Development Bank (IDB) established the World Waqf Foundation (WWF) in 2001 in collaboration with world waqf organizations, Non- Governmental Organizations (NGOs) and philanthropists from the private sector with an aim to improve on socio-economic development of Muslim communities' worldwide (IDB, 2015).

In 2015, Malaysia's Bank Muamalat Malaysia Berhad (BMMB) has allocated approximately USD24 mil (RM100 mil) to develop 4.47ha of waqf land via collaborations with UDA Waqf Sdn. Bhd., a wholly-owned unit of UDA Holdings Bhd. The development of waqf land is part of the company's ongoing effort to ensure the growth and diversification of waqf assets, maximize its potentials and increase its value as well as ensuring its continuous benefits (The Star Online, 2015).Taking all the above factors into considerations, waqf is a powerful socio-economic vehicle that, if efficiently managed, has the ability to eradicate poverty, establish socio-economic justice and achieve equitable distribution in a society. Pledged assets in waqf are utilized to fund real economic activities or financial investments and the returns from these are then used to achieve the societal welfare and social benefits (MIFC, 2015). The contributions of waqf for economic and social development and sustainability can be explained, among others, as follows:

a. Reducing government expenditure and participation in the economy

Essentially, waqf is not a part of government income or expenditure, rather it is a charity given voluntarily by well-to-do Muslim people in the society to serve public interests and enhance their welfare. Having financed by waqf fund, the government therefore, can save a great amount of its budget and expenditure which initially planned for public interests. This 
budget then could be effectively channeled to other important development activities. It is in this sense that waqf institution can replace the government's burden and responsibility and reduce its participation in the economy (Nik Hassan, 2008).

The more the waqf fund collected for certain development projects beneficial to the society, the lesser the government's portion will be for those particular projects. Waqf can place the government participation in the economy in the right proportion and perspective. In the present globalized economy, the private sector should be given a much greater space to actively participate in economic development as an efficiency-driven economy normally can be pushed by this private sector. The economics of innovation and creativity can be nurtured when the private sector has plenty opportunities to maneuver. The institution of waqf can encourage bigger private sector participation through voluntary actions and reduce government involvement in the economy (Nik Hassan, 2008).

\section{b. Preventing deficit financing and decreasing rate of interest}

Government borrowing through deficit financing basically can be prevented by active society's commitment to social economic requirements. Deficit financing normally has a bad financial impacts on the government. In the present volatile world economic condition, the public sector should reduce its public borrowings to prevent possible crises in the future. The previous financial crises affecting East Asian countries gave a valuable lesson that huge borrowings by the public as well as private sectors, particularly from external sources, brought about excessively negative effects on the region (Nik Hassan, 2008).

Cizakca (1998) asserted that waqf system can significantly contribute to massive reduction in government expenditure. This in turn leads to a reduction in the budget deficit, which decreases the need for government borrowing and curbs the "crowding-out effect". Eventually, this also brings about a reduction in the rate of interest which constitutes a basic impediment for private investment and growth. Thus, the role of waqf for lowering interest rate by providing the most essential social services without any cost to the government. A reestablishment and revitalization of the waqf system should be considered as a vital step in the struggle to eliminate riba. Accordingly, the gradual elimination or reduction of interest through the waqf system should be taken into consideration. The waqf could fulfill these functions by voluntary donations made by the well to do people. Thus, privately accumulated capital may be voluntarily endowed to finance and develop social services to the society without being trapped into deficit financing at all.

\section{c. Restoring distribution of income and wealth}

Waqf institution also plays important role to achieve a just distribution of wealth and income in the economy. Nik Hassan (2008) considered that through voluntary contributions of the rich for the public purpose, waqf can have a positive implication on the redistribution of wealth. This kind of voluntary approach has a much better result than the redistribution through taxes and government transfer expenditure as the instrument of taxes has a greater costs implication for its implementation. Due to a lack of proper tax formulation, the costs of collecting taxes may create unnecessary burdens to the government. Likewise, in the transfer of 
government expenditure, it involves a great cost. On the contrary, in the form of waqf, the costs of collection will be very cheap and in most cases it even involves no cost at all.

Islamic teachings highly recommend individuals to give alms to the poor or to spend money through waqf mechanism, in addition to zakat, for the benefit of general public. Through such voluntary mechanism, individuals are helping the authorities to improve the condition of the society. As waqf made by the rich people provides benefit to the society in general and the poor in particular, this feature serves to alleviate the effects of income and wealth inequality. Different from the short-term impact of government budgetary policies, the institution of waqf could eliminate the tendency towards concentration of wealth among society (Siddiqi, 1996).

\section{d. Eradicating poverty}

Poverty and income inequality have always been among the most critical and enduring problems that the societies face. There are ways to handle the poverty problems, starting from preventive to curative measures. An important way to alleviate poverty as considered by Sadeq (2002) is charity, which has been playing a role and can potentially be an effective means to overcome these acute problems. Charity has many forms, but a long lasting form of charity is one that has the characteristic of perpetuity. The institution of waqf is such a perpetual charity in the Islamic system.

Waqf may also be formed purposely to disseminate knowledge and coach skills in entrepreneurship development among the poor as microfinance alone cannot create wealth unless combined with entrepreneurial skills. Indeed all technical assistance programs including for poverty alleviation can be organized as waqf (Obaidullah and Khan, 2008). Nik Hassan (2008) reminded that it had been attested in the past, particularly during the Ottoman Empire, that waqf and economy were highly connected in a positive direction. As the waqf institution was flourishing, the country's economy was also advancing. The bigger the size of waqf properties, the bigger the size of private sector involvement and the more progress the economy.

\section{LITERATURE REVIEW}

Prior to this research, a lot of research regarding cash waqf and waqf bank have been done by several scholars and researchers in recent time. Tahir (2010) explains that the waqf bank can be applied as the bank of the poor. It is permissible in Islam based on validity of cash waqf and the need of waqf, its beneficiaries as well as the society. But, if there is favourable political will, the institution of waqf through waqf bank may contribute to society greatly. The institutions of waqf have the unrealized potential to establish a waqf bank.In addition, several studies have been conducted to show a true picture on the willingness of Muslims in Malaysia to contribute for the establishment of Islamic waqf bank. Muhammad Ridhwan et. al. (2013) explain about the waqf bank that can be applied in the market and also concluded that there is a possible structure for waqf bank model and instrument that can be implemented in the future for the financing in education.

Farhah Saifuddin et. al. (2014) concluded that with the support of the Malaysian government along with the private sector and general public, the institution of waqf in general and cash waqf in specific could develop and prosper in order to play important roles in the 
socio development of policy implementation in the country.Besides, MohdAsyraf et. al. (2013) conclude that each and every level of income of the respondent are willing to contribute for Islamic waqf bank. This is because each and every one of them is aware of the important of education and the possibility that Islamic waqf bank will support their children in the future. The willingness of each Muslim to contribute for Islamic waqf bank is very high, thus will lead to the establishment of Islamic waqf bank.

Meanwhile, GunawanBaharuddin et. al. (2014) conclude that the establishment of waqf bank is as important as the need to develop a micro-financing institution, seeing the pattern of rapid development of Islamic banks, but did not cause significant changes to the welfare of the poor. The gap between the rich and poor is getting wider and income inequality, making the need for a social bank urgent than ever. The establishment of waqf bank is expected to help the country's efforts to improve a better standard of living, education, health, employment and the like to the people.

A study by Muhammad Ridhwan Ab. Aziz et. al. (2013) entitled "Assessment on the Willingness among Public in Contributing For Social Islamic Waqf Bankfor Education" shows that nearly $80 \%$ of the total 231 respondents agree and strongly agree with the use of agents as representatives in raising fund for Islamic waqf bank. Another study which has been conducted by Muhammad Ridhwan Ab. Aziz et al. (2015) entitled "Investigating the Relationship between Level of Income, Method of Contribution and Appointment of Islamic Waqf Bank as an Agent in Collecting Waqf Fund" shows that $40 \%$ of the respondents strongly agree and 39\% of respondents agree that electronic payments can be used to facilitate the donation of cash waqf funds through Islamic waqf bank.

Muhammad Ridhwan Ab. Aziz et. al. (2013) conclude that there is a high readiness among Muslims in Malaysia to donate funds for Islamic waqf bank covering various levels of income earners either for low-income or high-income earners. The only reason the respondent reluctant to contribute to the Islamic waqf bank is due to their lack of knowledge and understanding regarding waqf and low level of confidence towards Islamic waqf bank as a trustee in collecting waqf fund.

In addition, Muhammad Ridhwan et. al. (2013) clarify that students are more motivated to pursue their studies if they obtain free education through Islamic waqf bank, where this mechanism may reduce cost and burden in accommodating for their studies. Besides, a descriptive study on 96 male and 114 female respondents indicated that the majority of male respondents strongly agreed with the fact that Islamic waqf bank is an alternative for financing for higher education. A total of 66 male respondents strongly agreed with this statement and 22 are agreed. Only 6 respondents were not sure with this statement. For female respondents, 63 out of 114 respondents who answered the questionnaire strongly agreed with the statement and 47 of them agreed that Islamic waqf bank could be an alternative for higher education funding. Only 4 female respondents are uncertain with this fact (Muhammad Ridhwan Ab. Aziz et. al., 2014).

The above studies show that the Muslim community in Malaysia are strongly supported the establishment of Islamic waqf bank and they are willing to contribute through cash waqf mechanisms to finance not only the education sector, but can also be extended to other important 
sectors such as health, social and welfare. Their willingness to contribute to the Islamic waqf bank are not only focused on those who obtain high income of more than RM8,000 (USD1,971) per month, but also for those who are earning below RM3000 (USD739) per month. Thus, by realizing the establishment of waqfbank, it may help to promote free education among Muslim and to offer various welfare services that able to enrich the development of Muslim ummah through proper and systematic way of funding via waqf arrangement.

\section{RESEARCH METHODOLOGY}

In this study, qualitative method has been used through personal in-depth interview. The interviews have been conducted with experts, practitioners and academicians in the field of Islamic economics, Islamic banking, economic development and waqf. This study also employs documentary review in order to strength the general findings in this research. Electronic recording devices audio are used and the voices from the recording devices are transcribed. A total number of six respondents are voluntarily participated in this study. The information generated from the face to face in-depth semi structure interview conducted with the aim of obtaining primary data for the study was transcribed and analyzed. The advantages of using interview method in this study, among others are useful to obtain detailed information about personal feelings, perceptions and opinions, they allow more detailed questions to be asked, respondents' own words are recorded, and ambiguities can be clarified and incomplete answers can be followed up. Thus, these advantages will give benefits for this study (Raymond Opdenakker, 2006).

Interviews play a crucial role for the robustness of this study. Thus, the purpose of interview is to get other people's perspectives and how they render meanings on events of interest or the process of getting information out of their thinking (Marginson, D. E. W. 2004). The process of getting inside interviewees thought has the potential to offer a greater understanding of how waqf works in various organizations and how this research can develop deposit and financing instruments for waqf bank. Therefore, interview is considered as a conversation with purpose of acquiring knowledge from interviewees(O'Dwyer, B. 2004). In this research, a semi-structured interview is employed to flesh out the theory underpinning the holistic deposit and financinginstruments for waqf bank.

The semi-structured interview is used since it offers greater opportunities to tap into realities beyond the interviews' contexts as compared to a structured interview. The semistructured interviews were carried out based on an interview guide. A semi-structured interview informed by prior understanding can guide the process, but not to the point of structuring the queries (Irvine, H. \&Gaffikin, M. 2006). These are the two tasks that the interviewer or researcher must always bear in mind:

a) To follow researcher own line of inquiry, as reflected by interview protocol.

b) To ask actual (conversational) questions in an unbiased manner.

If an interviewer only assumes the task (a) of following his/her own line of inquiry, it might be possible that this research be inclined towards a structured interview, which could also be found in a positivist approach because the interview might serve as a diagnostic effort. On the other hand, if only task (b) is emphasized, it would bear similarity to an unstructured 
interview, which might be found more often in an interpretive approach (Ahrens, T. \& Chapman, C. S. 2006).

The data collected have be analyzed by specific theme in order to achieve objectives of the research. Finally, a new structure of deposit and financing instruments for waqf bank based on waqf arrangement has been developed.

A total of six respondents were interviewed in a semi structured interview for the same set of questions. The interview was utilized to understand the issue regarding waqf bank from respondents who have in-depth knowledge regarding waqf and Islamic banking. Due to the complexity of the subject matter, not all officers in the organization were interviewed. Only those who are expert in the field of waqfand Islamic banking were interviewed. The list of respondents'profile from each category of respondent is listed in Table 1 below. Table 1 below shows the detail of the interviewees for this study including the designation, field of expertise, gender and educational background.

Table 1: Details of Interviewees

\begin{tabular}{|c|c|c|c|c|}
\hline Respondent & Designation & Field of expertise & Gender & Educational Background \\
\hline $\mathrm{R} 1$ & $\begin{array}{l}\text { Associate } \\
\text { Professor Dr. }\end{array}$ & Waqf, Muamalat & Male & $\begin{array}{ll}\text { - PhD (Islamic Studies/ Islamic } \\
\text { Economics), USM } \\
\text { Master in Islamic Studies/ } \\
\text { Islamic Economics, USM } \\
\text { Bachelor in Economic } \\
\text { Development and Planning, } \\
\text { UKM }\end{array}$ \\
\hline $\mathrm{R} 2$ & Doctor & Waqf, Muamalat & Male & $\begin{array}{ll} & \text { PhD (Syariah and Muamalat), } \\
\text { UiTM } \\
\text { Master in Hadith, University of } \\
\text { Malaya } \\
\text { - } \\
\text { Bachelor in Islamic Studies, Al- } \\
\text { Azhar University. }\end{array}$ \\
\hline R3 & $\begin{array}{l}\text { Associate } \\
\text { Professor Dr. }\end{array}$ & Islamic Banking & Female & $\begin{array}{ll}\text { - } & \text { PhD (Islamic Banking and } \\
\text { Finance), International Islamic } \\
\text { University Malaysia } \\
\text { - } & \text { Master in Shariah (Islamic } \\
& \text { Banking), Universiti Malaya } \\
\text { - } & \text { Bachelor in Shariah (Hons) } \\
\text { Economics, Universiti Malaya }\end{array}$ \\
\hline $\mathrm{R} 4$ & Prof. Dato'.Dr. & $\begin{array}{l}\text { E c o n o } \mathrm{m} \mathrm{i} \mathrm{c} \text {, } \\
\text { Islamic Finance, } \\
\text { Waqf Financing }\end{array}$ & Male & $\begin{array}{l}\text { - PhD (Economics), University of } \\
\text { Southampton } \\
\text { Master in Applied Economics, } \\
\text { Monash University } \\
\text { Bachelor in Economics } \\
\text { and Econometrics, Monash } \\
\text { University }\end{array}$ \\
\hline
\end{tabular}




\begin{tabular}{|c|c|c|c|c|}
\hline Respondent & Designation & Field of expertise & Gender & Educational Background \\
\hline R5 & $\begin{array}{l}\text { Deputy Mufti } \\
\text { of Selangor, } \\
\text { Department } \\
\text { ofMufti Selangor }\end{array}$ & $\begin{array}{l}\text { Waqf, Fiqh Islam, } \\
\text { FiqhMualamat }\end{array}$ & Male & $\begin{array}{l}\text { PhD (Fiqh and Usul), } \\
\text { The World Islamic Science and } \\
\text { Education University, Jordan. } \\
\text { Master in Islamic Philosophy, } \\
\text { Cairo University } \\
\text { - Bachelor in Syariah Islamiyah, } \\
\text { Universiti al-Azhar al-Syarif }\end{array}$ \\
\hline R6 & $\begin{array}{l}\text { Head of Bandar } \\
\text { Baru Nilai } \\
\text { Branch, Bank } \\
\text { Islam Malaysia } \\
\text { Berhad }\end{array}$ & $\begin{array}{l}\text { Islamic Finance, } \\
\text { Finance, } \\
\text { Muamalat }\end{array}$ & Male & $\begin{array}{l}\text { - Bachelor in Banking and } \\
\text { Finance }\end{array}$ \\
\hline
\end{tabular}

Source: Developed for the current study

\section{FINDINGS AND DISCUSSION}

\section{A. Preliminary Findings}

From the general findings of this study, it shows that there is a proper mechanism that able to be applied for deposit and financing instruments based on cash waqf for waqf bank. This study provides how the deposit and financing instruments can be operated based on cash waqf for the possible establishment of waqf bank. The possible mechanism of deposit and financing instruments for waqf bank is based on several suggestions and recommendations by the respondents which have been interviewed.

In this study, the findings can be divided into two parts which is the proper mechanism for deposit instrument of waqf bank and the second is the proper mechanism for financing instrument of waqf bank.

\section{B. Proper Mechanism For Deposit Instrument Of Waqf Bank}

This section provides several suggestions of deposit instruments as suggested by the interviewees. The researchers try to focus on what are the possible structure of the deposit instruments based on the waqf arrangement for the waqf bank.

The findings of the study reveal that all the respondents in this study agree that the mechanism for the cash deposit should be based on the waqf for the waqf bank. Firstly, in terms of how the waqf bank able to become a trustee for cash waqf itself. As a new mechanism, the waqf bank becomes a medium for Muslims to endow their waqf money in the name of Allah SWT and for enhancing the development of Muslim society. Therefore, the role of waqf bank is to supervise and monitor the collection of waqf fund, investment and also distribution of profit to the charity activities (Mohammad Tahir Sabit Haji Mohammad, 2011).

According to R1 and R3:

".....there are two ways for Muslims to endow the waqf money into the waqf bank. The first way is by opening an account for the waqf endowment solely. This method is provided for Muslims who want to endow the waqf money regularly for instance once in a month. So, the account can be provided to show the amount of money which has 
been deposited by waqif as waqf money. The second way is to provide the cash waqf certificate for waqif. This method is provided for waqif who want to endow the money infrequently for instance once in a lifetime".

The waqf bank will collect the waqf money from the waqif and will act as a trustee for cash waqf. The waqf bank will manage and monitor cash waqf which have been deposited by the waqif. As R1 and R2 have said:

"the waqf bank will act as mutawalli which is a person/institution who has been given the responsibility to collect the waqf fund. Another role for a mutawalli is to manage the waqf fund accordance with the Islamic principles and existing laws in order to make sure that the waqf fund will be benefited to the needy".

The waqf bank will convert the cash waqf into the fixed assets such as buildings and lands. Through this way,it will put back the cash waqf into the original role of waqfwhich holding a property from the consumption for the purposed of extracting the usufruct for the benefit of the Muslim society in general. The waqf property must be in immovable and perpetuity. Hence, it is necessary to transform the cash money into the fixed assets based on the current value of the assets presently. According to R2 and R4:

"the most important thing for the establishment of waqf bank is to comply with the nature of waqf in Islam including the pillars and conditions. One of the natures is the waqf property must be in existence and perpetuity. The transformation into the fixed assets is necessary to avoid any doubt and mistrust towards the existence of cash waqf".

The waqf bank will act not only as a trustee, but it will monitor all activities of waqf including actual financing, investment and profit distribution. It will be done under a proper management of its cash waqf windows with good governance and efficient. According to R3:

"....in order to establish the new model of waqf bank, we must consider first the governance of it to identify a higher degree of moral social order in which all decisionmaking structures and authority ought to submit. Good governance may contribute to an efficient organization".

\section{Proper Mechanism For Financing Instruments Of Waqf Bank}

This section provides several suggestions and recommendations for the financing instruments of the waqf bank. In Shariah, the fundamental and standard mode of financing are musharakah and mudarabah. Since salam and istisna' contracts create real assets, so these are also allowed in Islam. Nonetheless, according to Shariah experts, when musharakah, mudarabah, salam and istisna' cannot be implemented or suitable, then murabahah and ijarah contract can be used by fulfilling certain conditions (Usmani, 1998). Thus, this article suggests the use of cash waqf fund for the best Islamic mode of financing such as musharakah, diminishing musharakah and mudarabah, or a combination of these two.

This mode of financing is very important because waqf fund can be used to increase profit from investment in order to finance the needy. Besides, the donor donates money not only to help poor people, but also to get reward in the hereafter or to satisfy Allah whereby, honesty 
is very important for successful musharakah and mudarabah contract (Md. ShehedurRahaman Chowdhury et. al, 2011). According to R3:

"waqf bank should identify the mode of investment which give a lot of profits and at the same time, it will produce less liabilities and avoid any loss to the earnings. It is important to achieve the original objectives of waqf bank which is to help the development of Muslims".

There are several investments that can be invented in order to gain profit from waqf bank. The first is the development of waqf land. The waqf bank will made a joint-venture with another company for the development of waqf land for commercial purposes. It can be known as waqf-sukuk. According to KhairunnisaMusari (2016), the issuance of waqf-sukuk becomes an innovative instrument in order to mantain and develop the waqfassets or waqffund. With many of waqfassets or cash, sukuk issuance can therefore be regarded as a tool to finance the development of waqfproperties or using them to be the underlying asset. The integration of sukuk and waqfin a single structure is an interesting development that is worth to develop.

R1, R2, R5 and R6explain that:

".......the issue of the State Islamic Religious Council (MAIN) on the management of waqf land. Nowadays, they have a lot of waqf land which have been endowed by Muslims, but they have lack of capital to develop and commercialize the waqf land. Therefore, the waqf-sukuk is necessary to overcome this problem in order to avoid the abundance of waqf land without benefiting Muslims generally. Waqf-sukuk can be integrated with the principles of mudharabah and musharakah to develop the waqf land."

Secondly, waqf fund should be used to provide financing to small and medium enterprises (SME) due to the fact that SME is an emerging sector in underdeveloped and developing nations. If these sectors are neglected, then it would be impossible for these nations to make economic development in the future (Md. ShahedurRahaman Chowdhury et. al., 2011).

The profit from the financing and investment should be distributed according to the terms and agreements which have been signed by the waqif and the waqf bank. According to R3 and R4:

"when the waqif enters into an agreement with the waqf bank, the portion of profit will be distributed based on the waqif's will. Usually, the waqif will endow the waqf money for the purpose solely for Allah SWT and specifically for the Muslim development".

In this regard, it can be distributed in three ways. The first one is for the Muslims development in several major things such as education, health, agriculture, entrepreneurship and other development projects. It will become an alternative for current loan which has been provided by the financial institutions through the conventional banks and also Islamic banks. Most of peoplerequired the financial aid in order to help them to achieve the goals of setting the high standard of living especially among Muslims. For the education purposes, the needs of student towards the establishment of waqf bank is for the education purposes. There were strong demands for the establishment of Islamic waqf bank from the public especially among the students (Muhammad Ridhwan Ab. Aziz and MohdAsyraf Yusof, 2014). 
The second way is some percentages from the profit will be allocated to the management including for maintenance, managerial expensesand also for the future development and capital enhancement. It is necessary for the survival of the waqf bank for its existence, it becomes an alternative for giving financing instrument for Muslims. According to R1 and R2:

“.....the cost of operation and management of waqf bank, it cannot be taken from the fundamental or capital fund of the waqf. There must be an allocation from the profit of investment for the management of waqf bank".

Based on the finding of the deposit and financing instruments as explained above, below is the best model for both instruments of waqf bank (based on the findings in this research):

\section{FIGURE 1: DEPOSIT AND FINANCING INSTRUMENTS FOR WAQF BANK}



Source: Developed for the current study 
Based on Figure 1 above, this is the suggested process for the operation of deposit and financing instruments for waqf bank. Firstly, the person who is willing to endow the money into waqf bank is called as a waqifor depositor. The money will be deposited into the waqf bank as cash waqf, stipulated that the elements and conditions of waqf must be fulfilled. The amount of money is unfixed based on the willingness of the depositor. Then, certificate of cash waqf will be produced as a proof of the amount of money which has been deposited by the depositor.

In order to preserve the nature of the waqf, the waqf bank will act as a mutawalli or trustee of the cash waqf. The waqf bank will transform the waqf money into the fixed assets such as land and buildings. It depends on the discretion of waqf bank on converting the waqf money into the fixed assets based on the current value. The waqf bank will develop and commercialize the fixed assets such as land and buildings to gain profits in the form of rental or income. After that, the profits gained will be used as funds for the Muslims development in several major areas such as health, education and economic development including for various financing schemes for the poor and non-bankable customers.

\section{CONCLUSION}

From this article, it can be concluded that through innovative way of cash waqfmanagement for waqf bank, it able to provide many benefits to all level of society especially for the poor and middle group of people, which generally are not reachable by the government or other agencies. The establishment of waqf bank may become a new alternative for Muslims who want to endow their money as waqf deed to fulfill religious requirement and obedience to Allah SWT, thus waqf bank will become a proper and right place for them. This bank can create employment opportunity to develop socioeconomic conditions of the poor and whole society as the ultimate goal. The waqf bank will provide financing for the needy as an alternative for current loan which are provided by the commercial banking institutions. The permissibility of cash waqf and the suitability of capital structure of waqf bank can be considered as waqf instrument in solving the financial problem among Muslims especially in many underdeveloped countries worldwide.

\section{Acknowledgement}

This research is benefited from the funding of the External Collaboration Grant (ECG) of the Yayasan Pembangunan Ekonomi Islam Malaysia (YAPEIM), (Developing Deposit and Financing Instruments Based on Waqf for Islamic Waqf Bank) (USIM/YAPEIM/ FEM/052002/43017).

\section{REFERENCES}

Alhabshi, S. O., (1991), Waqf management in Malaysia. In Mohamed Ariff (ed.), The Islamic voluntary sector in Southeast Asia. Singapore: Institute of Southeast Asian Studies.

Ando, A. \& F. Modigliani, (1963), "The 'life cycle' hypothesis of saving: Aggregate implications and tests", The American Economic Review, 53(1), 55-84.

Bello, W., (2008), 'Primer on Wall Street Meltdown.' Casino Crash. Transnational Institute \& Institute for Policy Studies. 3 October. URL: http://casinocrash.org/?p=11. 
Bernama . "Waqf Can Be Financing Source For Wealth Distribution: Perak Regent", November 2014.

Bonner, M., (2005), Poverty and economics in the Qur'an. Journal of Interdisciplinary History, Vol. 35(3), 391-406.

Chowdhury, Md. ShahedurRahaman, et. al., (2011), "Economics of Cash WAQF Management in Malaysia: A proposed Cash WAQF model for practitioners and future researchers ", African Journal of Business Management, Vol.5(30).

Çizakça, M., (...$)$, A History of philanthropic foundations: The Islamic world from the seventh century to the present. Istanbul: Bogazici University Press.

Çizakça, Murat, (199^) Awqaf in History and Its McGagraw-Hill, $r$ ed. Implications for Modern Islamic Economies, Islamic Economic Studies, Vol. 6, No. 1, Jeddah: IRTI.

Çizakça, Murat, (199^), "Awqaf In History And Its Implications For Modern Islamic Economies", Islamic Economic Studies, Vol. 6, No. 1, Jeddah: IRTI \& IDB.

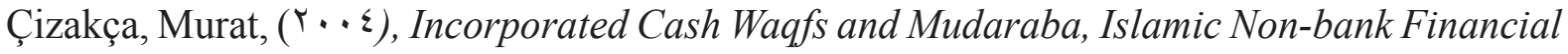
Instruments From the Past to the Future, Turkey: Bahcesehir University.

Farhah Binti Saifuddin, SaimKadibi, RefikPolat, Yahya Fidan, Omer Kayadibi (2014), "The Role of Cash Waqf in Poverty Alleviation: Case of Malaysia", Seminar Waqf Iqlimi, UniversitiSains Islam Malaysia, 29 $9^{\text {th }}$ April 2014.

Federal Reserve System, (2008), Flow of Funds Accounts. Data from website www. federalreserve.gov/. Data downloaded on various dates in November and December.

Fuadah Johari, Mohammad Haji Alias, Muhammad Ridhwan Ab. Aziz, ZurinaKefeli, Nursilah Ahmad, Kalsom Abd Wahab, Fauzi Abu Hussin and Patmawati Haji Ibrahim (2015), "Identifying the Potential of Continuity in Cash Waqf Contribution: A Descriptive Analysis", The Journal of Muamalat and Islamic Finance Research Vol. 12/No.2 2015.

GunawanBaharuddin and Bayu Taufiq Possumah (2014), "The Emergence of Waqf Bank; A Social Welfare Alternative", Conference: Workshop: Advanced Course on Social and Ecological Market Economy by University of Paramadina and Konrad Adenauer Stiftung., At Nusa Dua, Bali, October 2014.

Gupta, A., (2008), 'How to Wreck the Economy.' The Indypendent. 3 October. URL: http:// www.indypendent.org/2008/10/02/how-to-wreck-the-economy/.

Haji Mohammad, Mohammad Tahir Sabit\&Hj. Mar Iman, Abdul Hamid, (2006), “Obstacles of the Current Concept of Waqf to the Development of Waqf Properties and the Recommended Alternative", Malaysian Journal of Real Estate, 1(1).

Irvine, H. \&Gaffikin, M., (2006). "Getting in, getting on and getting out: reflections on a qualitative research project”. Accounting, Auditing \& Accountability Journal, Vol 19. No. 1. pp. 115-145.

Islamic Social Finance Report 2015, Jeddah: Islamic Research \& Training Institute (IRTI). 
Kahf, Monzer, (1998), "Financing the Development of Awqaf Property", Working Paper for the Seminar on Development of Awqafby IRTI, Kuala Lumpur, March 2-4.

KhairunnisaMusari (2016), "Waqf-Sukuk, Enhancing The Islamic Finance for Economic Sustainability in Higher Education Institutions", 2nd World Islamic University Leaders' Summit 2016 (WICULS 2016), 16th \& 17th November 2016.

Malaysia International Islamic Financial Centre (MIFC) Insight Report (2015), Islamic Finance: Promoting Real Economic Development. accessed at: www.mifc.com

Malaysia Islamic Finance (MIFC) Report (2015). Accessed at: http://www.irti.org/English/ News/Pages/Launch-of-the-Malaysia-Islamic- Finance-Report-2015.aspx

Marginson, D. E. W., (2004), “The case study, the interview and the issue: a personal reflection". in Humphrey, C. \& Lee, B. (Eds.) The real life guide to accounting research: a behindthe-scenes view of using qualitative research methods. Amsterdam: Elsevier.

Md. ShahedurRahaman Chowdhury, Mohd Fahmi bin Ghazali and MohdFaisol Ibrahim (2011), "Economics of Cash WAQF management in Malaysia: A proposed Cash WAQF model for practitioners and future researchers", African Journal of Business Management Vol. 5(30), pp. 12155-12163, 30 November, 2011.

Mohammad Tahir Sabit Haji Mohammad (2011), “Towards an Islamic Social (Waqf) Bank", International Journal of Trade, Economics and Finance, Vol. 2, No. 5, October 2011

MohdAsyrafYusof, Muhammad RidhwanAb. Aziz, andFuadah Johari(2013), “The Relationship between Level of Income and Willingness of Muslim Communiy to Contribute for Islamic Waqf Bank", 5 th Islamic Economics System Conference (iECONS 2013), "Sustainable Development Through the Islamic Economics System" 4-5 ${ }^{\text {th }}$ September 2013.

Muhammad Ridhwan Ab. Aziz \&Fuadah Johari \& Hisham Sabri, (2013) “Assessment on the Willingness among Public in Contributing For Social Islamic Waqf Bank for Education",Australian Journal of Basic and Applied Science. Vol. 7 (13).

Muhammad Ridhwan Ab. Aziz \&Fuadah Johari, Hisham Sabri, (2015),"Investigating the Relationship Between Level of Income, Method of Contribution and Appointment of Islamic Waqf Bank as an Agent in Collecting Waqf Fund". UlumIslamiyyah Journal, Vol.15.

Muhammad Ridhwan Ab. Aziz \&MohdAsyraf Yusof, (2014), “An Initial Study on Student's Need towards Islamic Waqf Bank for Education". International Conference on Arts, Economics and Management (ICAEM'14) March 22-23, 2014 Dubai (UAE).

Muhammad Ridhwan Ab. Aziz and MohdAsyraf Yusof, (2013), "The Inclination of Student and Public towards The Establishment of Islamic Waqf Bank", World Applied Sciences Journal, Vol.26, Issue: 1, November 2013.

Muhammad Ridhwan Ab. Aziz et. al., (ed.) (2014). Waqf Financing for Higher Education: Issues, Challenges and the Way Forward. Bandar Baru Nilai: USIM Press. 
Muhammad Ridhwan Ab. Aziz, (2012), Introduction to Islamic Institutions in Economics and Finance. Bandar Baru Nilai: USIM Press.

Muhammad Ridhwan Ab. Aziz, (2013), "The Relationship Between Level of Income and Willingness of Muslim Community to Contribute for Islamic Waqf Bank". Paper presented at The 5th Islamic Economic System Conference (iECONS) at Berjaya Times Square, Kuala Lumpur, 4-5 September 2013.

Muhammad Ridhwan Ab. Aziz, Fuadah Johari and MohdAsyraf Yusof, (2013), "Cash Waqf Model for Financing in Education", The 5th Islamic Economic System Conference, 4th - 5th September 2013, Kuala Lumpur, Malaysia.

Muslim, Abu al-Husayn, (2009-1430), Shahih Muslim, Ahmad Zahwah\& Ahmad 'Inayah (ed.), Lebanon: Daar al-Kutub al-'Araby.

Obaidullah, M. \& Khan, T., (2008), Islamic microfinance development: Challenges and initiatives. Jeddah: Islamic Development Bank.

O’Dwyer, B., (2004), "Qualitative data analysis: illuminating a process for transforming a 'messy' but 'attractive' 'nuisance'”, in Humphrey, C. \& Lee, B. (Eds.) The real life guide to accounting research: a behind-the-scenes view of using qualitative research methods. Amsterdam: Elsevier.

RB Dandy Raga Utama, ZaviraniFitrandasari, Moh. Arifin, RidanMuhtadi (2018), "Can Mosque Fund Management For Community Economic Empowerment?: An Exploratory Study", International Journal Of Islamic Business Ethics, Vol 3, No 2, 456.

Sadeq, A. H. M., (2002), Waqf, perpetual charity and poverty alleviation. International Journal of Social Economics, Vol. 29(1/2), 135-151.

Saripah Abdul Latif, Nik Muniyati Nik Din, and Zaiton Mustapha (2018), "The Role of Good Waqf Governance in Achieving Sustainable Development", ${ }^{\text {th }}$ AMER International Conference on Quality of Life, Perhentian Island, 03-04 March 2018 / E-BPJ, 3(7), Mar. 2018 .

Siddiqi, M. N., (1996), Role of the state in the economy: An Islamic perspective. Leicester: The Islamic Foundation.

The Star Online. "Bank Muamalat Allocates RM100mil to develop wakaf land”, January 2015.

Torbat, A. E., (2008), 'Global Financial Meltdown and the Demise of Neoliberalism.' Global Research. Centre for Research on Globalization. 13 October. URL: http://www. globalresearch.ca/index.php? context=va\&aid=10549.

Usmani T (1998). An introduction to Islamic Finance, Karachi. IdaratulMa'arif. 